\title{
สังคมงูพิษ: ปฏิสัมพันธ์ระหว่างงูเขียวหางไหม้ในประเทศไทย
}

เคิร์ท เอช. บาร์นส

มหาวิทยาลัยเทคโนโลยีสุรนารี สาขาวิชาชีววิทยา จังหวัดนครราชสีมา ประเทศไทย

ในอดีตการศึกษาพฤติกรรมทางสังคมของอสรพิษนั้นมีอยู่อย่างจำกัด แต่ความก้าวหน้าทางเทคโนโลยีสมัยใหม่ กลับท้าทายกระบวนทัศน์ที่ขาดหายไปต่อความสลับซับซ้อนทางสังคมของงูเขียวหางไหม้ ในระหว่างที่ทำการศึกษา พฤติกรรมทั่วไปของงูเขียวหางไหม้ในธรรมชาติ ณ สถานีวิจัยสิ่งแวดล้อมสะแกราชและมหาวิทยาลัยเทคโนโลยีสุรนารี นักวิจัยได้บันทึกการปฏิสัมพันธ์ที่พบได้ไม่บ่อยนักระหว่างงูเขียวหางไหม้ชนิดเดียวกันภายใต้การบันทึกจำนวน 13 ครั้ง ใน ตัวอย่างประชากร 6 ตัว ผ่านการติดตั้งกล้องบันทึกในพื้นที่ถิ่นอาศัยในป่าธรรมชาติ ชนบท และกึ่งเมืองกึ่งชนบท นักวิจัย ได้ทำการตรวจสอบปฏิสัมพันธ์ระหว่างตัวอย่างงูเขียวหางไหม้ที่ศึกษาหลักในงานวิจัยและงูีกตัวจากการบันทึกในขณะที่ ตัวอย่างกำลังดักซุ่ม โดยแบ่งการปฏิสัมพันธ์ออกเป็นทางตรงและทางอ้อมซึ่งจำแนกโดยอาศัยระยะความห่าง และผลลัพธ์ ของปฏิสัมพันธ์ ได้แก่ เป็นกลาง (neutral) ไขว้เขว (distracting) และ เป็นศัตรู (agonistic) จากการศึกษาพบว่า มีการ บันทึกปฏิสัมพันธ์ส่วนใหญ่เป็นแบบทางอ้อมจำนวน 7 ครั้ง และได้ผลลัพธ์แบบเป็นกลางจำนวน 6 ครั้ง สำหรับปฏิสัมพันธ์ แบบทางตรงได้รับการบันทึกจำนวน 6 ครั้ง โดยมีผลลัพธ์แบบ ไขว้เขว จำนวน 3 ครั้ง และเป็นศัตรู จำนวน 4 ครั้ง ทั้งนี้ นักวิจัยได้บันทึกปฏิสัมพันธทางตรงแบบเป็นศัตรูที่พบเจอได้ยากในการศึกษาครั้งนี้ขณะที่งูขขียวหางไหม้ทำการแย่งพื้นที่ ดักซุ่มและกัดงูอีกตัวที่หากินอยู่และถือเป็นการค้นพบครั้งใหม่สำหรับชนิดพันธุ์นี้ โดยการศึกษาทั้งหมดเกิดขึ้นในช่วงเวลา นอกฤดูผสมพันธุ์ ซึ่งเป็นช่วงเวลาเดียวกันที่พื้นที่อาศัย พื้นที่หากิน และจำนวนเหยื่อมีอยู่อย่างจำกัดและอาจเกิดจากปัจจัย แวดล้อมทางฤดูกาลที่ไม่เอื้ออำนวยต่อการใช้ชีวิตประกอบด้วย ถึงแม้การพบเจอปฏิสัมพันธ์ของงูเขียวหางไหม้กับงูอีกตัว ในธรรมชาติที่อาจเป็นไปได้ยากนี้ ทำให้มีการศึกษาวิจัยมีอยู่อย่างจำกัดและมีการประมานค่าของความสลับซับซ้อนทาง สังคมของงูเขียวหางไหม้ต่ำไป อาจส่งผลอย่างมีนัยยะสำคัญต่อการประยุกต์ใช้ในวิจัย การอนุรักษ์ และการจัดการปัญหางู กัดในอนาคตได้ งูเขียวหางไหม้สามารถเป็นตัวอย่างสิ่งมีชีวิตที่ทำให้เข้าใจพฤติกรรมทางสังคมของงูที่สลับซับซ้อน เนื่อง ด้วยลักษณะสัณฐานทางเพศที่เด่นชัดในกลุ่มชนิดพันธุ์เดียวกัน และความสูงของพื้นที่อาศัยของชนิดพันธุ์อื่น ๆ กลุ่มงูเขียว หางไหม้ที่ยังไม่ได้ทำการวิจัยอย่างเพียงพอในการศึกษาครั้งนี้ 